\title{
Comparative effect of pig manure, urea fertilizer and their combinations on the performance of Amaranthus cruentus in a rainforest Ultisol, Nigeria
}

\author{
Otobong B. Iren ${ }^{1^{\star}}$, Christiana J. Ijah², Damian O. Asawalam ${ }^{3}$ and Victor E. Osodeke ${ }^{3}$ \\ ${ }^{1}$ Department of Soil Science, University of Calabar, Calabar, Cross River State, Nigeria. \\ ${ }^{2}$ Department of Soil Science, Akwa Ibom State University, Akwa Ibom State, Nigeria. \\ ${ }^{3}$ Department of Soil Science and Meteorology, Michael Okpara University of Agriculture, Umudike, Abia State, Nigeria. \\ ${ }^{*}$ Corresponding author. E-mail: myirenlady@gmail.com. Tel: +2348035068991.
}

Copyright $@ 2016$ Iren et al. This article remains permanently open access under the terms of the Creative Commons Attribution License 4.0, which permits unrestricted use, distribution, and reproduction in any medium, provided the original work is properly cited.

Received 14th July, 2016; Accepted 23rd August, 2016

\begin{abstract}
The influence of pig manure, urea and their combinations on the performance of Amaranthus cruentus was investigated for two years in a rainforest Ultisol of Umudike. The experiment was laid down in a randomized complete block design with four replications. Six treatments consisted of pig manure applied at equivalent rates of $90 \mathrm{~kg}$ $\mathrm{N} / \mathrm{ha}$ as full dose of manure, urea at $60 \mathrm{~kg} \mathrm{~N} / \mathrm{ha}$ as full dose of urea. Other treatments were $1 / 2$ dose of manure $(45 \mathrm{~kg}$ $\mathrm{N} / \mathrm{ha})+1 / 2$ dose of urea $(30 \mathrm{~kg} \mathrm{~N} / \mathrm{ha}), 1 / 4$ dose of manure $(22.5 \mathrm{~kg} \mathrm{~N} / \mathrm{ha})+3 / 4$ dose of urea $(45 \mathrm{~kg} \mathrm{~N} / \mathrm{ha}), 3 / 4$ dose of manure $(67.5 \mathrm{~kg} \mathrm{~N} / \mathrm{ha})+1 / 4$ dose of urea $(15 \mathrm{~kg} \mathrm{~N} / \mathrm{ha})$, and the absolute control. Results indicated that Amaranthus plant height was not significantly $(P>0.05)$ affected by the treatments compared to the control. The overall results showed that the combination of $1 / 2$ manure $+1 / 2$ urea significantly $(P<0.05)$ increased stem girth $(17.42 \mathrm{~cm})$, number of leaves per plant (44.76), fresh yield (41.51 t/ha) and dry matter yield (3.49 t/ha) of Amaranthus than sole application of either of them, and is therefore recommended as the best for optimum production of Amaranthus in the study area.
\end{abstract}

Key words: Amaranthus, growth and development, soil fertility, yield.

\section{INTRODUCTION}

The maintenance of soil fertility is essential in achieving and sustaining high crop yields over time. Use of inorganic fertilizers has proven to be more convenient and impactful than the use of organic manures. The resulting soil physical degradation, increased soil acidity, and soil nutrient imbalance have drawn attention of researchers back to the use of manures. Application of organic materials as soil nutrients provides growthregulating substrates and improves the physical, chemical and microbial properties of the soil (Belay et al., 2001; Iren et al., 2015). Organic residues with high amount of sulphur (S) could reduce soil pH as a result of the addition of sulphate thereby neutralizing the acidity produced by the oxidation of $\mathrm{N}$ during decomposition. Sole use of organic manures to sustain high crop production has, however, been reported inadequate, as they are required in rather large quantities to meet crops' nutrient requirements because of their relatively low nutrient content (Palm et al., 1997).

It has been reported by several researchers (Satyanarayana et al., 2002; Adeniyan and Ojeniyi, 2005; Obasi et al., 2006, Iren et al., 2014) that high and sustainable crop yields are only possible with integrated use of inorganic fertilizers with organic manures. Complementary application of inorganic and organic nutrient sources increases nutrient availability and reduces losses by converting inorganic nitrogen into organic forms (Chand et al., 2006; Chen, 2008). It enhances the efficiency of the fertilizers and also reduces environmental problems that may arise from their use (Zublena et al., 1996; Hoffman et al., 2001).

Amaranthus also called African spinach, bush green, 
green leaf, amaranths in different parts of the world belongs to the family Amaranthaceae. Amaranthus species are a group of highly popular vegetables, belonging to many different species. They are the most commonly grown leafy vegetable of the lowland tropics in Asia and Africa. The commonly cultivated amaranth in Africa include: Amaranthus cruentus, $A$. dubius, $A$. spinosus, $A$. blitum, A. thunbergii, $A$. graecizans and $A$. caudatus, but only the $A$. Cruentus species is most commonly grown in Africa (Schippers, 2000). A. cruentus can be grown all through the year depending on the availability of water. Amaranthus cruentus is best recognized by its leaves that are twice or three times as long as wide and often have pointed leaf tip. Amaranthus has a high nutritional value because of the high levels of essential micro- nutrients like iron (an important element against anaemia), manganese and zinc (Mnkeni et al., 2007). It contains calcium, $\mathrm{Mg}$, carotene and niacin. Vitamin $\mathrm{A}$ and $\mathrm{C}$ are also present in significant levels. The protein found in young plants of amaranths can be important for people without access to meat or other sources of protein.

Amaranthus cruentus can be sown directly in seed bed with the entire plant harvested some 4 to 5 weeks after sowing (Schippers, 2000), or planted in nursery beds before transplanting them to the main field. According to Schippers (2000), transplanted seedlings are most commonly used for ratoon crops (with successive harvests), whereas direct sowing is the rule for a crop that is harvested by uprooting. The optimal spacing for plants to be harvested by uprooting is $10 \times 10 \mathrm{~cm}$, whereas for the one with successive harvests (ratoon crop), the optimum spacing is about $20 \times 20 \mathrm{~cm}$ (Schippers, 2000; Ayuba et al., 2001).

This study was conducted to determine the effect of sole and combined use of inorganic fertilizer, urea, and organic manure from pig on the performance of Amaranthus. It is also designed to establish the best combination of these nutrient sources for Amaranthus production in the Rainforest zone of Umudike, Nigeria.

\section{MATERIALS AND METHODS}

\section{Description of the Study Area}

This experiment was conducted during the dry season at the Research Farm of Michael Okpara University of Agriculture, Umudike, Abia State in Nigeria. Umudike is located in the humid forest zone of Nigeria and lies within latitude $05^{\circ} 29^{\prime} \mathrm{N}$ and longitude $07^{\circ} 33^{\prime} \mathrm{E}$, with an altitude of $122 \mathrm{~m}$ above sea level. The study area by the virtue of its latitudinal location falls within the humid tropics and hence enjoys humid tropical environment marked by two distinct seasons namely the rainy season and the dry season. Umudike is characterized by tropical wet (March
Table 1. Treatments used.

\begin{tabular}{llc}
\hline $\mathbf{S} / \mathbf{N}$ & Treatment & Rate (kg N/ha) \\
\hline 1 & Control & Absolutely no \\
2 & Manure $(\mathrm{m})$ & 90 \\
3 & Urea $(\mathrm{u})$ & 60 \\
4 & $1 / 2 \mathrm{~m}+1 / 2 \mathrm{u}$ & $45+30$ \\
5 & $3 / 4 \mathrm{~m}+1 / 4 \mathrm{U}$ & $22.5+45$ \\
6 & $1 / 4 \mathrm{~m}+3 / 4 \mathrm{U}$ & $67.5+15$ \\
\hline
\end{tabular}

Table 2. Chemical composition of pig manure.

\begin{tabular}{lc}
\hline Parameter & Value \\
\hline Org. C (\%) & 30.29 \\
Org. matter & 52.22 \\
Total N (\%) & 2.87 \\
C: N ratio & 10.55 \\
Total P $(\%)$ & 0.21 \\
Total K (\%) & 1.80 \\
Ca $(\%)$ & 4.0 \\
Mg $(\%)$ & 1.8 \\
\hline
\end{tabular}

to October) and dry (November to February) seasons. Annual rainfall in Umudike ranges from $1900 \mathrm{~mm}$ to 2650 $\mathrm{mm}$, bimodally distributed with peaks in the months of July and September (Iren and Osodeke, 2006). There is usually a short dry spell in August which is referred to as 'August break'.

The minimum and maximum temperatures ranged from 19 to $24^{\circ} \mathrm{C}$ and 28 to $34^{\circ} \mathrm{C}$ respectively. The minimum and maximum monthly relative humidity ranges from 39 to $81 \%$ and 52 to $87 \%$ respectively in the area. The soil is loamy sand, strongly acidic in reaction with low nutrient reserve (Iren et al., 2012) and classified as an Ultisol (Njoku et al., 2001).

\section{Treatments and experimental design}

There were six treatments replicated four times (Table 1). The treatments were pig manure applied at an equivalent of $90 \mathrm{~kg} \mathrm{~N} / \mathrm{ha}$ as full dose of manure, and urea applied at $60 \mathrm{~kg} \mathrm{~N} / \mathrm{ha}$ as full dose of urea. Other treatments were $1 / 2$ dose of manure $(45 \mathrm{~kg} \mathrm{~N} / \mathrm{ha})+1 / 2$ dose of urea $(30 \mathrm{~kg}$ $\mathrm{N} / \mathrm{ha}), 1 / 4$ dose of manure $(22.5 \mathrm{~kg} \mathrm{~N} / \mathrm{ha})+3 / 4$ dose of urea (45 kg N/ha), $3 / 4$ dose of manure $(67.5 \mathrm{~kg} \mathrm{~N} / \mathrm{ha})+1 / 4$ dose of urea (15 kg N/ha) and absolute control. Pig manure rates were calculated based on its nitrogen $(\mathrm{N})$ content of $2.87 \%$ (Table 2).

The experimental design used was a randomized complete block design. Each experimental plot measured $3 \mathrm{~m} \times 1.5 \mathrm{~m}\left(4.5 \mathrm{~m}^{2}\right)$ with an alley of $1.2 \mathrm{~m}$ left between blocks and spacing of $0.6 \mathrm{~m}$ between plots. Pig manure 
Table 3. Effect of pig manure and urea fertilizer on the height of Amaranthus plant in the $1^{\text {st }}$ and $2^{\text {nd }} \mathrm{cropping}$ seasons.

\begin{tabular}{|c|c|c|c|c|c|c|c|c|c|}
\hline \multirow{3}{*}{ Treatments } & \multicolumn{9}{|c|}{ Plant height (cm) } \\
\hline & \multicolumn{3}{|c|}{ 3WAP } & \multicolumn{3}{|c|}{ 4WAP } & \multicolumn{3}{|c|}{ 5WAP } \\
\hline & $1^{\text {st }}$ & $2^{\text {nd }}$ & Mean & $1^{\text {st }}$ & $2^{\text {nd }}$ & Mean & $1^{\text {st }}$ & $2^{\text {nd }}$ & Mean \\
\hline Control & 12.25 & 12.3 & 12.28 & 24.35 & 23.45 & 23.9 & 56.6 & 55.75 & 56.18 \\
\hline Manure (m) & 15.85 & 14.2 & 15.03 & 32.45 & 29.45 & 30.95 & 70.8 & 63.65 & 67.23 \\
\hline Urea (u) & 18.1 & 16.6 & 17.35 & 37.65 & 36.2 & 18.46 & 78.35 & 72.8 & 75.58 \\
\hline $1 / 2 m+1 / 2 u$ & 16.95 & 17 & 16.98 & 39.28 & 39.3 & 39.29 & 76.23 & 76.36 & 76.3 \\
\hline $3 / 4 m+1 / 4 u$ & 17.75 & 16.4 & 17.08 & 35.65 & 32.5 & 34.08 & 73.4 & 68.9 & 71.15 \\
\hline $1 / 4 m+3 / 4 u$ & 19 & 15.9 & 17.45 & 38.45 & 35.1 & 36.78 & 77.45 & 70.25 & 73.85 \\
\hline $\operatorname{LSD}(0.05)$ & NS & NS & NS & NS & NS & NS & NS & NS & NS \\
\hline
\end{tabular}

was applied one week before planting (WBP) by broadcast with incorporation method (Iren et al., 2011). Urea fertilizer was applied two weeks after planting (WAP) by band placement method.

Amaranthus seeds were mixed with dried river sand before sowing so as to ensure the seeds were not planted too close together for proper management of the seed rate desired. The mixture was $70 \%$ sand and $30 \%$ Amaranthus seeds. These were evenly distributed directly on drills at a distance of $10 \mathrm{~cm}$ between each row. The seedlings were later thinned to one plant per stand few days after emergence at a spacing of $10 \mathrm{~cm}$ between plants. Therefore, the planting distance was 10 $\mathrm{cm} \times 10 \mathrm{~cm}$ giving plant population of 450 plants per bed equivalent to $1,000,000$ plants per hectare $\left(10,000 \mathrm{~m}^{2}\right)$. The plots were kept weed free throughout the crop growing period by hand pulling because of the closeness of the plants. Plots were irrigated manually using watering cans before planting and immediately after planting to ensure germination and enhance sprouting. Watering was done 2 times a day (morning and evening) at the initial stage of development and this was reduced to ones (evening only) every day till the end of the experiment. During this time there was a good canopy development that shaded the ground and reduced soil moisture loss.

\section{Data Collection}

Agronomic parameters measured included plant height, number of leaves per plant, stem girth, fresh yield and dry matter yield. Plant height was measured with a meter rule as the height from the base of the crop (ground level) to the tip of ten tagged plants, while the number of leaves was taken to be the fully opened leaves per plant. These measurements commenced 3 weeks after plating (WAP) and continued at weekly interval until the end of the experiment. Harvesting was done at 5 WAP by uprooting the entire plant from an area of $100 \mathrm{~cm} \times 100 \mathrm{~cm}$ per plot and the fresh yield determined after rinsing the roots free of sand. For dry matter determination, ten tagged plants were uprooted, rinsed, and oven-dried at $65{ }^{\circ} \mathrm{C}$ to constant weight (Maerere et al., 2001) and the weight determined using digital balance. Stem girth was measured at harvest using venier caliper. The data on fresh and dry yield were converted into t/ha using the formula below:

Yield $(\mathrm{t} / \mathrm{ha})=\frac{W T \times 10^{-2}}{P A}$

Where $W T=$ weight of Amaranthus (g), $P A=$ plot area $\left(\mathrm{m}^{2}\right), 10^{-2}=$ conversion factor because $1 \mathrm{ha}=10^{4} \mathrm{~m}^{2}$ and $1 \mathrm{t}=10^{6} \mathrm{~g}$ or $10^{3} \mathrm{~kg}$.

\section{Data Analysis}

The data collected were subjected to analysis of variance (ANOVA) using the general linear models (GLM) procedures of the Statistical Analysis System Programme (SAS, 1989) to determine treatment effects. Means were separated using Fisher's Least Significant Difference (FLSD) at $5 \%$ level of probability.

\section{RESULTS}

\section{Effect of Pig Manures and urea Fertilizer on Growth parameters of Amaranthus}

The height of Amaranthus plants was not significantly ( $P$ $>0.05$ ) affected by the pig manures and urea fertilizers being sole and/or combined (Table 3 ).

There was no significant $(P>0.05)$ difference in the mean number of leaves per plant at 3 WAP from the use of pig manure and urea fertilizer in the first and second cropping seasons (Table 4). However, results indicated that these treatments significantly $(P<0.05)$ increased the 
Table 4. Effect of pig manure and urea on mean number of leaves per Amaranthus plant in the $1^{\text {st }}$ and $2^{\text {nd }}$ cropping seasons.

\begin{tabular}{lccccccccc}
\hline & \multicolumn{8}{c}{ Number of leaves per plant } \\
\hline Treatments & \multicolumn{3}{c}{ 3WAP } & \multicolumn{7}{c}{ 4WAP } & & 5WAP \\
\hline & $\mathbf{1}^{\text {st }}$ & $\mathbf{2}^{\text {nd }}$ & Mean & $\mathbf{1}^{\text {st }}$ & $\mathbf{2}^{\text {nd }}$ & Mean & $\mathbf{1}^{\text {st }}$ & $\mathbf{2}^{\text {nd }}$ & Mean \\
\hline Control & 13.27 & 12.05 & 12.66 & 23.45 & 21.37 & 22.41 & 35.4 & 35.43 & 35.42 \\
Manure (m) & 14.4 & 14.1 & 14.25 & 26.44 & 25.43 & 26.44 & 43.8 & 41.8 & 42.8 \\
Urea $(\mathrm{u})$ & 15.95 & 14.55 & 15.25 & 26.63 & 26.08 & 26.36 & 43.18 & 41.75 & 42.47 \\
$1 / 2 \mathrm{~m}+1 / 2 \mathrm{u}$ & 15.6 & 14.48 & 15.04 & 27 & 28.3 & 27.65 & 44.78 & 44.75 & 44.77 \\
$3 / 4 \mathrm{~m}+1 / 4 \mathrm{U}$ & 14.3 & 14.2 & 14.25 & 26.08 & 24.43 & 25.26 & 42.75 & 40.85 & 41.8 \\
$1 / 4 \mathrm{~m}+3 / 4 \mathrm{u}$ & 15.38 & 14.46 & 14.92 & 27.15 & 26.33 & 26.74 & 44.82 & 44.55 & 44.69 \\
$\mathrm{LSD}(0.05)$ & NS & NS & 1.06 & 2.19 & 2.81 & 1.91 & 3.65 & 5.04 & 2.85 \\
\hline
\end{tabular}

Table 5. Effect of pig manure and urea fertilizer on Amaranthus stem girth in the $1^{\text {st }}$ and $2^{\text {nd }}$ cropping seasons.

\begin{tabular}{lccc}
\hline \multirow{2}{*}{ Treatment } & \multicolumn{3}{c}{ Stem girth $\mathbf{( c m )}$} \\
\cline { 2 - 4 } & $\mathbf{1}^{\text {st }}$ cropping & $\mathbf{2}^{\text {nd }}$ cropping & Mean \\
\hline Control & 9.98 & 9.58 & 9.77 \\
Manure & 14.20 & 17.03 & 13.96 \\
Urea & 16.60 & 13.83 & 15.47 \\
$1 / 2 \mathrm{~m}+1 / 2 \mathrm{U}$ & 17.83 & 13.73 & 17.42 \\
$3 / 4 \mathrm{~m}+1 / 4 \mathrm{U}$ & 15.25 & 14.90 & 14.54 \\
$1 / 4 \mathrm{~m}+3 / 4 \mathrm{U}$ & 16.53 & 14.35 & 15.71 \\
$\mathrm{LSD}(0.05)$ & 2.98 & 2.57 & 1.86 \\
\hline
\end{tabular}

number of leaves per plant relative to the absolute control at 4 and 5 WAP. Results also indicated that the highest mean number of leaves per plant (27.65 and 44.77) was obtained from the $1 / 2$ pig manure $+1 / 2$ urea fertilizer combinations.

The biggest stem girth of Amaranthus was obtained from the $1 / 2$ manure $+1 / 2$ urea treatment and the least by the absolute control in both seasons (Table 5), although in the first cropping season, the $1 / 2$ manure $+1 / 2$ urea treatment was significantly different from the sole manure treatment but not with the other treatments. In the second cropping season, the $1 / 2$ manure $+1 / 2$ urea was significantly different in stem girth from all the treatments except the $1 / 4 m+3 / 4 \mathrm{u}$. The results showed that the biggest stem girth $(17.42 \mathrm{~cm})$ was obtained from the $1 / 2$ manure $+1 / 2$ urea treatment.

\section{Effect of pig manure and urea fertilizer on fresh and dry matter yield of Amaranthus}

The highest fresh yield of Amaranthus of $42.80 \mathrm{t} / \mathrm{ha}$ obtained from application of $1 / 4$ manure $+3 / 4$ urea in the first cropping season was significant compared to the sole pig manure and the absolute control (Table 6). The highest yield of $41.01 \mathrm{t} /$ ha obtained from application of $1 / 2$ manure $+1 / 2$ urea in the second cropping season was significant relative to the absolute control. The mean data for the two years indicated that $1 / 2$ manure $+1 / 2$ urea recorded the highest fresh yield of $41.51 \mathrm{t} / \mathrm{ha}$, followed by $1 / 4$ manure $+3 / 4$ urea (41.40 t/ha) and the absolute control $(22.75 \mathrm{t} / \mathrm{ha})$ was the least. The highest dry matter yield (3.49 t/ha) was also obtained from $1 / 2$ manure $+1 / 2$ urea combination (Table 6).

\section{DISCUSSION}

The best result on the performance of Amaranthus was obtained from combined use of organic pig manure and inorganic urea fertilizer. This could be attributed to the organic influence of the pig manure on the microbial activities and soil moisture and/or temperature and the easy release of nutrients induced by salt index of urea. These findings are in line with those obtained by Satyanarayana et al. (2002), Adeniyan and Ojeniyi (2005), Adediran et al. (2005), Obasi et al. (2006) Iren et al. (2011 and 2012) and Iren et al. (2014). Most of their findings indicate better effect of organic materials on Amaranthus when applied in combination with inorganic 
Table 6. Effect of pig manure and urea on Amaranthus fresh and dry matter yields in the $1^{\text {st }}$ and $2^{\text {nd }}$ cropping seasons.

\begin{tabular}{lcccccc}
\hline \multirow{2}{*}{ Treatments } & \multicolumn{3}{c}{ Fresh yield (t/ha) } & \multicolumn{3}{c}{ Dry matter yield (t/ha) } \\
\cline { 2 - 7 } & $\mathbf{1}^{\text {st }}$ cropping & $\mathbf{2}^{\text {nd }}$ cropping & Mean & $\mathbf{1}^{\text {st }}$ cropping & $\mathbf{2}^{\text {nd }}$ cropping & Mean \\
\hline Control & 23.50 & 22.00 & 22.75 & 2.20 & 2.11 & 2.16 \\
Manure & 31.80 & 32.11 & 31.96 & 3.31 & 3.20 & 3.26 \\
Urea & 41.13 & 39.97 & 40.55 & 3.02 & 3.01 & 3.02 \\
$1 / 2 \mathrm{~m}+1 / 2 \mathrm{U}$ & 42.00 & 41.01 & 41.51 & 3.68 & 3.29 & 3.49 \\
$3 / 4 \mathrm{~m}+1 / 4 \mathrm{U}$ & 37.00 & 32.51 & 34.76 & 3.22 & 3.13 & 3.18 \\
$1 / 4 \mathrm{~m}+3 / 4 \mathrm{U}$ & 42.80 & 40.00 & 41.40 & 3.56 & 3.19 & 3.38 \\
$\mathrm{LSD}(0.05)$ & 9.96 & 9.87 & 9.25 & 0.91 & 0.91 & $\mathrm{NS}$ \\
\hline
\end{tabular}

fertilizers.

Generally, the fresh yields obtained from all the treatments except the absolute control in both the first and second cropping seasons were higher than the 25 t/ha. These are the optimum yields reported by Tandon (1991) and Messiaen (1992), and the maximum was 30 t/ha reported by Schippers (2000). This shows that Amaranthus responded positively to the various types of soil amendments. The highest dry matter yields obtained from $1 / 2$ manure $+1 / 2$ urea combination concurs with those obtained by Palm et al. (1997), Adeniyan and Ojeniyi (2005) and Chen (2008).

\section{Conclusion}

This study showed that balanced use of both organic manure and inorganic fertilizer enhanced optimum growth and yield of Amaranthus compared to sole application of either of them. The combination of $45 \mathrm{~kg} \mathrm{~N} / \mathrm{ha}$ of the pig manure (1/2 of full dose manure) and $30 \mathrm{~kg} \mathrm{~N} / \mathrm{ha}$ of urea ( $1 / 2$ of full dose urea) was not significantly different. They were also statistically similar to those from the combination of $22.5 \mathrm{~kg} \mathrm{~N} / \mathrm{ha}$ of pig manure (1/4 manure) and $45 \mathrm{~kg}$ $\mathrm{N} /$ ha of urea $(3 / 4$ urea). However, combination of $1 / 2$ of each full dose gave significant improvement in the performance of Amaranthus and is therefore recommended as the best for optimum production of Amaranthus with similar environments and climatic conditions.

\section{CONFLICT OF INTEREST}

The authors declare that they have no conflict of interest.

\section{REFERENCES}

Adediran, J. A., Akande, M. O. and Akanbi, W. B. (2005). Effect of organic root plus (Biostimulant) on nutrient content, growth and yield of tomato. Nigerian Journal of Soil Science, 15, 2633.
Adeniyan, O. N. and Ojeniyi, S. O. (2005). Effect of poultry manure, NPK 15-15-15 and combination of their reduced levels on maize growth and soil chemical properties. Nigerian Journal of Soil Science, 15, 34-41.

Ayuba, S. A.; Attah, E. S., \& Ali, E. A. T. (2001). Growth response of Amaranthus (Amaranthus cruentus $L$ ) to application of urea and organic manure under irrigation. Proceedings of the $27^{\text {th }}$ Annual conference of the Soil Science Society of Nigeria, 226- 230.

Belay, A., Classens, A. S., Wehner, F. C., \& Beer, J. D. (2001). Influence of residual manure on selected nutrient elements and microbial composition of soil under long-term crop rotation. South African Journal of Plant and Soil, 18, 1-6.

Chand, S., Anwar, M., \& Patra, D. D. (2006). Influence of longterm application of organic and inorganic fertilizers to build up soil fertility and nutrient uptake in mint-mustard cropping sequence. Communications in Soil Science and Plant Analysis, 37:63-76.

Chen, J. (2008). The combined use of chemical and organic fertilizers and/or Bio fertilizer for growth and soil fertility. Food and Fertilizer Technology Center (FFTC) Database, Taiwan.

Hoffman, I., Gerling, D., Kyiogwon, U.S., \& Mane-Bieldfeldt, A. (2001). Farmer's management strategies to maintain soil fertility in a remote area in northwest Nigeria. Agriculture, Ecosystem and Environment, 86, 263-275.

Iren, O. B., \& Osodeke, V. E. (2006). Estimation of Water Requirements of Early and Late Season Pepper (Capsicum annum) in Umudike, South-Eastern Nigeria. Global Journal of Agricultural Sciences, 5 (2), 95-99.

Iren, O. B., Akpan, J. F., Ediene, V. F., \& Asanga, E. E. (2015). Influence of cassava peels and poultry manure-based compost on soil properties, growth and yield of waterleaf (Talinum triangulare Jacq) in an ultisol of south-eastern Nigeria. Journal of Soil Science and Environmental Management, 6(7), 187-194.

Iren, O. B., Asawalam, D. O., \& Osodeke, V. E. (2011). Effects of Time and Method of pig manure application on growth parameters and yield of Amaranthus cruentus in a Rainforest Ultisol in Nigeria. Production Agriculture and Technology (PAT) Journal, 7(1), 103-116.

Iren, O. B., Asawalam, D. O., Osodeke, V. E., \& John, N. M. (2012). Comparative effects of animal manures and urea fertilizer on soil properties in a Rainforest Ultisol. Journal of Agricultural Research and Policies, 6(2), 51-56.

Iren, O. B., John, N. M., \& Imuk, E. A. (2014). Effects of sole and combined applications of organic manures and urea on 
soil properties and yield of fluted pumpkin (Telfairia occidentalis, Hook f.). Nigerian Journal of Soil Science, 24(1), 125-133.

Maerere, A. P., Kimbi, G. G., \& Nonga, D. L. M. (2001). Comparative effectiveness of animal manures on soil chemical properties, yield and root growth of Amaranthus (Amaranthus Cruentus L.). African Journal of Science and Technology, 1(4), 14-21.

Messiaen, C. M. (1992). The tropical vegetable garden: Principles for improvements and increased production with application to the main vegetable types, $514 \mathrm{p}$.

Mnkeni, A. P.; Masika, P., \& Maphaha, M. (2007). Nutritional quality of vegetable and seed from different accessions of Amaranthus in South Africa. Water SA, 33(3), 377-380.

Obasi, M. N., Mbanaso, E. N. A. Ano, A. O., \& Onwubiko, O. (2006). Effect of combination of organic materials and mineral fertilizer on the growth and yield of cocoyam. Proceedings of the $40^{\text {th }}$ conference of the Agricultural Society of Nigeria (ASN), Umudike, 386-388.

Palm, C. A., Myers, R. J. K., \& Nandwa, S. M. (1997). Combined use of organic and inorganic nutrient sources for soil fertility maintenance and replenishment. In: Replenishing soil fertility in Africa. Buresh, R. J., Sanchez, P. A., \& Calhoun, F. (Eds). Special Publication, Soil Science Society of America, Madison WI, 51, 193-217.
SAS (Statistical Analysis System) (1989). Statistical Analysis System User's guide: Statistics SAS Institute.

Satyanarayana, V. M., Vera Prasad, P. V., Murphy, V. R. K., \& Boots, K. J. (2002). Influence of integrated use of farmyard manure and inorganic fertilizer on yield and yield components of irrigated lowland rice. Journal of Plant Nutrition, 25(10), 2081-2090.

Schippers, R. R. (2000). African indigenous vegetables. An overview of the cultivated species. Chatham, UK: Natural Resources Institute / ACP-EU Technical Centre for Agricultural and Rural Cooperation, 214p.

Tandon, H. L. S. (1991). Fertilizer recommendation for horticultural crops. A Guidebook. $2^{\text {nd }}$ ed. Fertilizer Development and Consultation Organization, New Delhi, India, 104p.

Zublena, J. P., Barker, J. C., \& Carter, T. A. (1996). Poultry manure as a fertilizer source. In: Water quality and waste management. North Carolina Cooperative Extension Service, 439- 456. 